Article

\title{
Media Literacy in Montenegro
}

\author{
Jelena Perović \\ Department of Communication and Social Research, La Sapienza University of Rome, 00198 Rome, Italy; \\ E-Mail:.jperovic@t-com.me
}

Submitted: 28 May 2015 | In Revised Form: 17 August 2015 | Accepted: 21 October 2015 |

Published: 29 December 2015

\begin{abstract}
Few countries in the world have introduced media education into their curriculums. Montenegro became one of them in 2009, when "media literacy" was introduced as an optional subject for 16 and 17 year old students of Gymnasium high schools. This article presents the findings of the first and only research conducted so far on media education in Montenegro. It is a national case study which examines the potential of media education to change the school culture and accelerate education system reform towards embracing the new digital education paradigm in the future. The focus is on the results of research conducted through in-depth interviews with media literacy teachers all over the country. Despite the many challenges, all teachers identify the potential of media education to strengthen some of the key competences of the students and to improve their motivation and academic performance. They also identify potential to change positively school culture by transforming teachers into "cultural mediators" (Morcellini, 2007) and by supporting the formation of a "participative culture" (Jenkins \& Kelley, 2013) in schools. This research recommends focusing education reform on spreading the media education pedagogy to the entire curriculum in order to embrace the new digital education paradigm in the future.
\end{abstract}

\section{Keywords}

children; civic participation; creative media production; critical thinking; media education; media literacy; media pedagogy; Montenegro; youth

\section{Issue}

This article is part of the special issue "Turbulences of the Central and Eastern European Media", edited by Epp Lauk (University of Jyväskylä, Finland).

(C) 2015 by the author; licensee Cogitatio (Lisbon, Portugal). This article is licensed under a Creative Commons Attribution 4.0 International License (CC BY).

\section{Introduction}

"The skills, practices and dispositions students are encouraged to develop are filtered through a system designed for an outdated world. The system, built on a "just-in-case" model of learning (Collins \& Halverson, 2009), prepares learners for a life of information consumption but not of active circulation, of critical analysis but not of creative activity (Lankshear \& Knobel, 2007)." (Jenkins \& Kelley, 2013, kindle loc 523-533 of 4643)

The digital revolution introduced changes that are leading to a new digital communication paradigm, which will need a corresponding, new digital education paradigm. Technological changes have led to a dramatic increase in the number of people who are not only acting as the audience, but also as authors of messages through multiple media platforms at the same time. Such a thing was not possible in the pre-digital age. Hence, there is a shift from individual to collective media engagement, collaboration and networking. (Perez Tornero \& Varis, 2010). Consequently, both the key concepts of media literacy and its research methodology need to be updated in order to be relevant for the digital media and participatory culture (Jenkins, 2010). Also, school pedagogy and curriculum must follow these changes in order to teach the competencies that students will need in the society of the $21^{\text {st }}$ century. In other words, within the digital society, schools will 
have to embrace a new, digital education paradigm.

In particular, in this context, the notion of media literacy needs to be updated to include digital literacy. Similarly, in order not to remain analogue in a digital world, schools need to teach both the old and new literacies. The new literacies are known under different terms in the international scientific debate-critical literacy and digital literacies (Carrington \& Robinson, 2009; Jones \& Hafner, 2012), critical digital literacy (Dowdall, 2009), new media literacies (Jenkins \& Kelley, 2013), media literacy 2.0 (Hoechsmann \& Poyntz, 2012), media literacy (Perez Tornero \& Varis, 2010), etc.

Digital competence, which one needs to acquire in order to become digitally literate, is defined as "the ability to access, analyze, evaluate and communicate messages in a variety of forms" (Aufderheide, 1993; Christ \& Potter, 1998).

The concept of digital competence is widely discussed and this article refers to the model of digital competences developed by Cortoni and Lo Presti (2014). It identifies five types of digital competences: access, critical thinking, creative media production, media awareness and civic participation.

In the following paragraphs, each type of these competences is briefly explained. Further, this article connects five types of digital competences to the international scientific debate and hence, proposes a map of digital competences presented in Figure 1.

The access competence refers to the students' ability to "read and write" digital media. Hence, they need to learn not only linear, but also non-linear reading typical for the digital media (Ferri, 2011; Simone, 2012; Veen \& Vrakking, 2006) and thus, develop iconographic competences (Veen \& Vrakking, 2006). Students also need to be able to respond to the text in the digital language or to learn "participatory reading" (Jenkins \& Kelley, 2013). Since today's students live in an attention economy (Goldhaber, 1997), it is crucial for them to acquire the multitasking competences (Jenkins, 2010). They also need to be aware of the different digital languages or of the subcategories of the netspeak (Crystal, 2001) such as the language of emails, the language of the chat groups and so on. Similarly, Gee (2008) talks about the need to know social languages and explains how users of different affinity spaces-those contributing to a blog, those playing an online game or friends of one social network-tend to use "social language" that differentiates them from the members of other groups. Also, students need to know to communicate through emoticon (Jones \& Hafner, 2012). Finally, they need to be aware of the cultures of use of different media (Jones \& Hafner, 2012), which depend on the interaction between the medium advantages and disadvantages and the expectations, norms and vales that different users connect to it.

The critical thinking competence is related to the ability to reflect critically on the media contents. It includes the ability to perform zapping, i.e. identifying essential information in the ocean of messages and images and constructing a meaningful system of knowledge based on it (Veen \& Vrakking, 2006). It also includes filtering or the ability to select and prioritize information (Jones \& Hafner, 2012). Further, this competence includes both networking, the ability to search, summarize and disseminate information, and the transmedia navigation or the capacity to follow a stream of stories and information through different media platforms (Jenkins, 2010).

The creative media production competence refers to the capacity to write for the digital media or to express oneself and interact effectively through the production of new contents and messages. Hence, the students need to learn to use effectively specific languages of different digital media and online communities such as, for example, blogging, video blogging and digital storytelling (Jones \& Hafner, 2012). They also need to become capable of using and modifying different contents already available online. In other words, they need to be able to remix or modify some aspects of an existing message and mash-up or mix two or more messages to make a new one, (Jenkins \& Kelley, 2013; Jones \& Hafner, 2012; Manovich, 2007) while respecting the copyright and, particularly, the rules related to the Creative Commons Licensing (Lessig, 2004). Further, this competence includes the capacity to appropriate media or to use them in a new social context (Jones \& Hafner, 2012). Also, sometimes, students need to be able to adapt or use the medium in a way that was not originally programmed by the inventor to make it more appropriate to the personal objectives (Jones \& Hafner, 2012). Players of video games often do this by adding new content to the game or creating a new game based on the elements of the available one and the mod indicates the modified videogame. (Jones \& Hafner, 2012). This competence also includes the ability of mixing two or more media in a way to combine their advantages in order to overcome their limits and do new things which none of these media can do alone (Jones \& Hafner, 2012). Finally, since we are constantly exposed to a huge number of messages, students need to learn how to draw attention and make their messages interesting by acquiring competences like the ones that Lankshear and Knobel propose. These two authors use the word "memeing" to indicate the ability to disseminate ideas, while they refer to the ability to share information with "attention transacting" and to the ability to link the messages with celebrities to ensure greater dissemination with "transferring". Further, they talk about the ability to make attractive messages and call it "contact displaying", as well as about the ability to present different points of views, which they indicate as "framing and encapsulating" (Lankshear \& Knobel, 2007). All of these competences fall under the category of the creative media production, as they teach the student how to 
make an interesting message, how to disseminate it effectively to different audiences and how to draw more attention to it by sharing it with the greatest number of people possible.

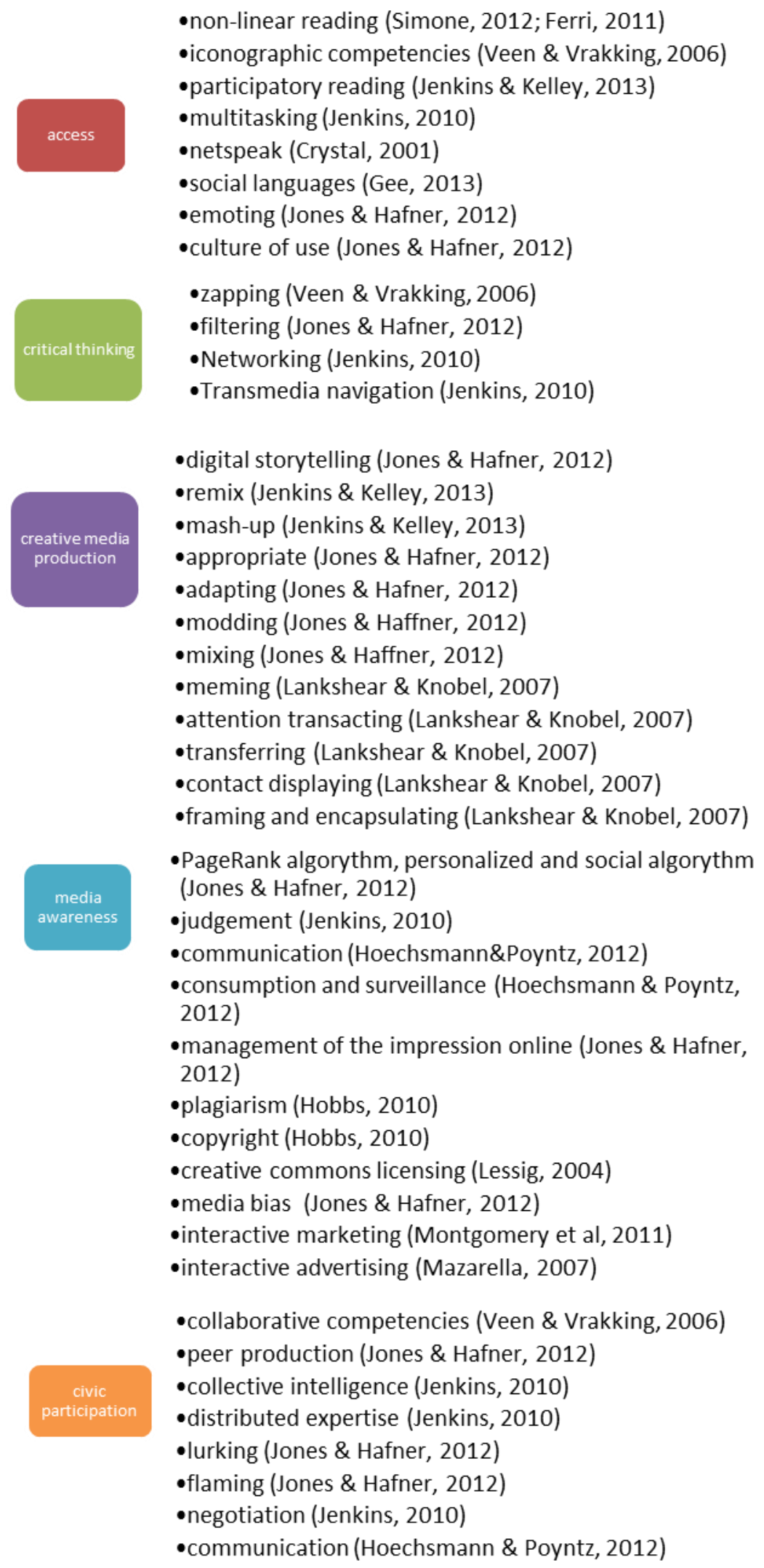

Figure 1. The map of digital competences. 
The media awareness competence refers to the ability to use the media to communicate while respecting cultural differences, privacy and, in general, the norms of the specific sociocultural context within which one interacts. To start with, students need to acquire an awareness of how their reading of messages on digital media is conditioned by the way these media function. For example, they are limited in the reading of hypertext by the choice of links proposed by the author (Jones \& Hafner, 2012). Similarly, they need to understand meanings of the PageRank algorithm (used by the Google search engine to rate the relevance of items appearing in a search based on their hypertextual relations with other items online), personalized algorithm (which filters and ranks data based on the user's personal choices and past behaviour online) and social algorithm (which allows groups of people to filter and rank data one for another) (Jones \& Hafner, 2012). Moreover, students also need to be able to assess the credibility and reliability of different sources of information online. This competence is described as "judgement" by Jenkins (2010) and as "communication" by Hoechsmann \& Poyntz (2012). Further, the school needs to teach about the media bias or the way different media distort our vision of the reality and the way in which we can interact with it. (Jones \& Hafner, 2012) This fundamental ability for a critical media awareness is already part of media literacy 1.0 and it now needs to be updated with reference to the digital media. Also, having in mind the new forms of marketing for children-interactive marketing (Montgomery, Grier, Chester, \& Dorfman, 2011) or interactive advertising (Mazzarella, 2007)-which disseminate the same message through different media, all the competences which make students capable of critically reflecting on the media and of using them with critical awareness become essential in the digital age. Further, consumption and surveillance are examples of competences that need to be taught in order to make students aware of the privacy and the economic model that is behind the social networks - the sale of the data about the users to the advertising agencies (Hoechsmann \& Poyntz, 2012). Hence, students need to learn to manage properly their identities and relations online in order to acquire the competence of the management of the online impression (Jones \& Hafner, 2012). Finally, they need to become aware of the concepts of copyright and plagiarism, which assume a new meaning in the remix culture.

"Plagiarism is using someone else's work without attribution....Although the conduct of plagiarism may overlap with copyright infringement, the two concepts are distinct. You can plagiarize from Shakespeare, but you'll never have a copyright problem, since his works are in the public domain. Plagiarism is an ethical problem handled by teachers and schools; copyright infringement is a legal problem handled by courts." (Hobbs, 2010, p. 8)
For this purpose, students need to practice remix, mash-up, appropriating, adapting, modding, digital story-telling and similar competences in order to fully understand the meaning of plagiarism and the legal and ethical framework of the alternative to the copyright known as the Creative Commons Licensing born after the digital revolution (Lessig, 2004).

Finally, the fifth competence of civic participation refers to the effective use of media aimed at taking part in the society, community and different professional, social and cultural networks. First, the definition of culture needs to be updated to include the online culture and the introduction of students to the norms and practices of socialization in different online communities, social networks or affinity spaces (Jones \& Hafner, 2012). For example, affinity spaces are online spaces where people interact in order to promote a specific interest or achieve a common objective (Gee, 2013). Hence, the school needs to teach collaborative competences (Veen \& Vrakking, 2006) like peer production or the collaborative production of information in which a large number of volunteers, connected through a network, work together to promote certain projects (Jones \& Hafner, 2012). Second, students need to acquire the competence of collective intelligence or the ability to put together their knowledge and confront their opinions with others in order to achieve a common objective. Similarly, they need the competence of distributed expertise or the ability to interact in a meaningful way with instruments that expand mental capacities (Jenkins, 2010).

Knowledge is, thus, shared through a large network of persons and instruments and anyone can access it through the new media. Wikipedia is an example of an online space where students can practice all of these competences and be part of the participatory culture (Jenkins, 2010). Therefore, within schools, students should access networked publics in order to acquire, within this new context, the competences which are necessary for public participation in the digital age (Ito et al., 2009). For example, they need to develop competences like lurking or being present in an online space like a chatroom or a message-board without participating in the interactions. Since there are abuses online, students also need to learn to be responsible members of the participatory culture and to recognize and stop flaming i.e. abusing someone online (Jones \& Hafner, 2012). Finally, the online space is often much more multicultural than the offline one and so, students need to learn to respect different cultures and points of view by acquiring competences like negotiation (Jenkins, 2010) and communication (Hoechsmann \& Poyntz, 2012).

Now, in order to teach digital competences effectively, the school needs to make its pedagogy "digital". Many pedagogical principles proposed by scientists worldwide for this purpose are not new, as they belong to the ongoing transformation of pedagogy in the last 
decades. However, these principles are an essential part of the future digital education paradigm. Although they are cross-cutting, Table 1 links various cultural and educational practices proposed by authors for teaching digital competences with the type of digital competence that they seems most relevant to and this is further explained in the following paragraphs.

Parallel pedagogy stands for teaching old and new literacies together at the same time, as students can analyse the advantages and disadvantages and similarities and differences of different media (Chaka, 2009; Jenkins \& Kelley, 2013; Leander, 2009). In this way, students develop both the access and the media awareness competences.

In order to be more effective and motivating for students growing up in the digital world, schools need to acquire more flexibility in learning, contents, group work, etc. (Cortoni, 2009; Gee, 2013; Jenkins \& Kelley, 2013; Veen \& Vrakking, 2006) This is particularly important for developing the access competence, as when one does not know much about the new media, it is essential to motivate him/her to overcome the dig- ital divide through a flexible learning approach.

In order to develop students' critical thinking, media awareness and creative media production competences in the age of convergence, intertextuality and multimodality, it is necessary to have them study and compare how one text is presented in different media so that they can understand how it is disseminated and what impact it leaves on the contemporary culture. (Jenkins \& Kelley, 2013) This is done through critical framing (Kerin, 2009) and critical media production (Morrel et al., 2013).

Further, to develop the creative production competence, classes need to be organized according to the immersion principle, which has students immerged in a learning environment with multimedia resources (Veen \& Vrakking, 2006). This is similar to the experiences that students live in the out-of-school digital environment. For this reason, schools need to allow students more freedom to self-manage the learning process (Veen \& Vrakking, 2006). In this way, teachers are transformed in tutors or cultural mediators instead of being authorities who transmit the knowledge (Morcellini, 2007).

Table 1. The map of digital competences and the related educational and cultural practices.

\begin{tabular}{|c|c|c|}
\hline Type of competence & Digital competences & Educational and cultural practices \\
\hline Access & $\begin{array}{l}\text { non linear reading; iconographic } \\
\text { competences; participatory reading; } \\
\text { multi-tasking; zapping; filtering; } \\
\text { networking; transmedia navigation }\end{array}$ & $\begin{array}{l}\text { parallel pedagogy (Leander, 2009); flexibility } \\
\text { (Cortoni, 2009; Gee, 2013; Jenkins \& Kelley, } \\
\text { 2013; Veen \& Vrakking, 2006) }\end{array}$ \\
\hline Critical thinking & $\begin{array}{l}\text { judgement; communication; media bias; } \\
\text { interactive marketing; interactive } \\
\text { advertising; }\end{array}$ & $\begin{array}{l}\text { critical framing (Kerin, 2009); critical media } \\
\text { production (Morrel, Duenas, Garcia, \& Lopez, } \\
\text { 2013) }\end{array}$ \\
\hline $\begin{array}{l}\text { Creative media } \\
\text { production }\end{array}$ & $\begin{array}{l}\text { digital storytelling; remix; mash-up; } \\
\text { appropriating; adapting; modding; } \\
\text { memeing; attention transacting; } \\
\text { transferring; contact displaying; framing } \\
\text { and encapsulating }\end{array}$ & $\begin{array}{l}\text { immersion (Veen \& Vrakking, 2006); } \\
\text { transformed practice (Kerin, 2009); reading } \\
\text { with a mouse in hand (McWilliams \& Clinton, } \\
\text { 2013); fan fiction (Jenkins \& Kelley, 2013); overt } \\
\text { instruction (Kerin, 2009); self-management } \\
\text { (Veen \& Vrakking, 2006); cultural mediation } \\
\text { (Morcellini, 2007); critical media production } \\
\text { (Morrel et al., 2013) }\end{array}$ \\
\hline Media awareness & $\begin{array}{l}\text { PageRank algorithm, personalized and } \\
\text { social algorithm; netspeak; social } \\
\text { languages; cultures of use; negotiation; } \\
\text { communication; consumption and } \\
\text { surveillance; management of the } \\
\text { impression online; plagiarism; copyright; } \\
\text { creative commons licensing }\end{array}$ & $\begin{array}{l}\text { parallel pedagogy (Leander, 2009); } \\
\text { participatory reading (Jenkins \& Kelley, 2013); } \\
\text { critical framing (Kerin, 2009); critical media } \\
\text { production (Morrel et al., 2013) }\end{array}$ \\
\hline Civic participation & $\begin{array}{l}\text { peer production; collective intelligence; } \\
\text { distributed expertise; lurking; flaming }\end{array}$ & $\begin{array}{l}\text { collaborative learning (Davies, 2009); co- } \\
\text { created learning (Jenkins \& Kelley, 2013); } \\
\text { participatory reading (Jenkins \& Kelley, 2013); } \\
\text { participatory assessment (Jenkins \& Kelley, } \\
\text { 2013) situated learning (Kerin, 2009) }\end{array}$ \\
\hline
\end{tabular}


Hence, what needs to happen more often is overt instruction or a close collaboration between the teacher and the student, which is essential especially for developing the creative production competence (Kerin, 2009). Further, teachers need to apply the transformed practice or to have students recreate texts in class with different media and, thus, become responsible and creative authors (Kerin, 2009). A similar concept is referred to as reading with a mouse in hand by McWilliams and Klinton (2013), who emphasize the need to have children respond to what they read by creating new texts, correcting information available online in relation to it, etc. Similarly, Jenkins and Kelley (2013) suggest to use regularly fan fiction as an English language class activity, because it invites students to respond actively to the literature by becoming authors of new texts. They use the term participatory reading to describe the situation where all readers become also writers in class. This is essential for developing the civic participation competence as well.

Collaborative learning (Davies, 2009) and cocreated learning (Jenkins \& Kelley, 2013) are crucial for developing collaborative competences (Veen \& Vrakking, 2006), which are necessary for civic participation. The assessment of students also needs to support this and become participatory (Jenkins \& Kelley, 2013) and allow for a situated learning (Kerin, 2009).

To conclude, students of the 21st century need digital competences and in order to teach them, schools need to change pedagogy by making it more flexible and student-centred, so that the teacher becomes an interactive guide who stimulates collaboration and critical reflection in class. These changes will lead to a new digital education paradigm, which many scientists see already delineating in the media education (Gee, 2013; Hobbs, 2011; Jenkins \& Kelley, 2013; Morcellini \& Cortoni, 2007; Veen \& Vrakking, 2006; etc.)

This article focuses on a national case study related to Montenegro, which examines the potential of media education to change the school culture and accelerate the education system reform towards embracing the new digital education paradigm in future.

Not many countries in the world have introduced media education in the curriculum and Montenegro became one of them in 2009, when "media literacy" was introduced as one of 38 optional subjects in Gymnasium high schools, which encompass natural sciences, languages, social sciences and arts. Media literacy is a one year course aimed at students who are 16 and 17 years old. Two classes of media literacy per week are held during two semesters and so, this is not a subject that can be taken at the final exams of the high school since the total number of classes is below the criteria for this purpose.

The aim of the subject is for the student to acquire the competences which are necessary for critically receiving and producing media messages. Critical thinking and media production are identified as the two key dimensions of media literacy which prepare the student to become an active citizen in a democratic society.

The program includes the study of all media, including the digital ones, and it consists of seven modules: access to media; media message as a construct; media language; reception of media messages; system of values; the aim of the media message; and media, ethics and politics. Therefore, the course supports the students to develop all five types of digital competences discussed above.

Media literacy has been taught in every second Gymnasium high school and to students in one half of Montenegrin municipalities so far. Minority of these schools have taught it every year continuously due to practical issues having often to do with supporting teachers who lack a specific number of classes to fill in the norm by prioritizing the optional subjects which they can teach.

This article presents the findings of the first and only research conducted so far on media education in Montenegro. The focus is on the results of the qualitative part of the research conducted with Montenegrin media literacy teachers. They are typically Montenegrin language and literature teachers (although they can be psychology, sociology, philosophy or other social science teachers as well) and most of them have been trained to teach media literacy.

\section{Methodology}

In order to understand Montenegrin context of media literacy, the way it is taught and the extent to which it influences the school culture, in-depth interviews were conducted, in 2013, with 11 media literacy teachers in 10 municipalities out of the total of 11 municipalities where it has been taught since it was introduced.

In particular, the interview was aimed at collecting information about:

- How teachers define media literacy and the objectives of the subject they teach; if they distinguish it from other literacies like the ICT, traditional language literacy, etc. and in which ways;

- What kind of pedagogy teachers use in order to understand if it can be improved and how

- What kind of technological and professional support teachers need;

-What resources (texts, manuals, online resources, etc.) teachers use to prepare the classes; how useful they find the resources which were provided to them and what they lack;

- The teachers' point of view in relation to the reasons for which students choose to study media literacy;

- If there is any collaboration between schools and with local communities and media; 
- If and how media literacy can help the education system reform;

- What are the key challenges that media literacy faces in Montenegro and how to overcome them.

Every interview was conducted as a spontaneous conversation in which the researcher listened to the teachers carefully and used the interview questions to stimulate them to describe better their experiences.

The questions used as a guide are presented in Table 2, which connects them with their objectives-to research about the objectives, curriculum, teaching methods, support provided to teachers and impact of the course.

Table 2. Preparation of the interview with media literacy teachers in Montenegro.

Objective of the interview: to understand the objectives, teaching methodology, curriculum, results of the teaching of media literacy and the support provided to the teachers

Questions guiding the interview:

Objective of the question-

explore about

What are the objectives of the media literacy that you teach?

COURSE OBJECTIVES

How is media literacy different from the ICT classes in your school? And how is it

CURRICULUM

different from the critical analysis of texts during the language and literature

classes?

What type of activities do you do with students during class? Would you please give

TEACHING METHODOLOGY some examples?

Do you do media production with students? If yes, do you share the results of it with others? With whom, how, when, where...? What kind of reactions did you

encounter?

What is the predominant activity in media education: production, analysis, simple alphabetization, etc.

How do you assess the students? Do you use any guide for teachers in relation to this?

In your opinion, are students happy with the way that media literacy has been taught so far? Should something be changed in future?

What kind of technical support is available in your school? Are there cameras, computers, specific software or other tools for media literacy classes? Are there any problems in relation to this?

Have you received any training before starting to teach this subject? If yes, would you please describe what kind of training it was, when, where and by whom it was organized and if you found it useful and for what in particular?

What kind of training would you find useful now?

How do you use the texts provided for teachers-do you follow them exactly or use them as a guide for ideas that you later develop with students?

What do you think of school texts on media literacy?

Are there students who choose to study media literacy as an optional subject in your school every year? If not, why?

Why do students choose media literacy as an optional subject? What is your impression?

What is the academic achievement of the students who choose to study media literacy like? Did you register any changes before and after the course?

SUPPORT PROVIDED TO

TEACHERS

COURSE OBJECTIVES

In your opinion, can media literacy improve students' results at the PISA test? If yes,

how?

In your opinion, does media literacy change the school culture? If yes, how?

Have you ever received any feedback from parents about the classes? If yes, what

was it?

What do your colleagues think of media literacy? Are they interested to see the results of the students' work and to know more about it? Does the school management support media literacy and if yes, how?

In your opinion, would it be useful to teach media literacy to younger students as well and to the students of other high schools - professional ones and not just Gymnasium ones? How could this be organized in a sustainable way? 


\begin{tabular}{ll}
\hline Questions guiding the interview: & $\begin{array}{l}\text { Objective of the question- } \\
\text { explore about }\end{array}$ \\
\hline $\begin{array}{l}\text { Is there any kind of network of cooperation of Gymnasium high school media } \\
\text { literacy teachers and students? If yes, what is its function, how does it work, is it }\end{array}$ & $\begin{array}{l}\text { SUPPORT PROVIDED TO } \\
\text { TEACHERS }\end{array}$ \\
useful...? What is your opinion of it? If it does not exist, do you think it would be \\
useful and easy to organize something like that? \\
Have you had any cooperation with a TV or radio station, a newspaper or an \\
institute related to media literacy so far? If yes, would you please describe these \\
experiences? \\
Have you participated in any kind of project related to media literacy so far? If yes, \\
with whom, when, where, with what objectives and results? \\
In your opinion, what kind of projects would be useful for developing media literacy \\
in Montenegro in future? \\
In general, how would you define the major challenges to the development of \\
media literacy in Montenegro? And what needs to be done in future to overcome \\
them? \\
Hence, in your opinion, the priorities/objectives of media literacy in Montenegro in \\
future should be...
\end{tabular}

\section{Results}

Results of the qualitative research will be presented according to Figure 2: first, teachers' opinions about the objectives of the optional subject, then their opinions about the curriculum, teaching methodology, support provided to them and the impact of the course.

\subsection{Objectives}

As stated by the teacher T1, the objective of media literacy is to develop competences of "understanding, analysis and deconstruction of all media messages and of production of media messages in a way that respects media ethics and in order to promote certain ideas which can contribute to the general democratization of the society".

This definition is widely shared by all the teachers interviewed. Hence, media literacy is aimed at developing all five types of competences identified by Cortoni and Lo Presti (2014).

Definitions of the objectives of media literacy provided by Montenegrin teachers are in line with the ones presented by different scientists. First, teachers recognize two essential dimensions of media literacy-critical thinking and civic participation, which are also essential to different definitions provided within the scientific debate (Celot, 2014, pp. 3-4). Further, teachers define the objectives of media literacy at three levels-political, economic and socio-cultural in accordance with many scientists (Hobbs, 2011; Hoechsmann \& Poyntz, 2012; Jones \& Hafner, 2012; Jenkins \& Kelley, 2013; Gee, 2013; Potter, 2013; Perez Tornero \& Varis, 2010; etc.). At the political level, the aim is for the students to become critical towards the media messages that they receive or, in other words, to develop the competence of critical thinking. Further, the aim is for students to become capable of using the media to promote specific values and initiatives or to acquire the civic participation competence. At the economic level, students need to become aware of the links between the media and the economic power and this is related to their acquisition of the media awareness competence. Finally, at the socio-cultural level, teachers, like many scientists, see media literacy as a tool for making students aware of different stereotypes, for discussing various social issues like violence, privacy, etc. and for influencing the students' system of values in order to make it more tolerant and democratic. This last objective described by teachers corresponds to the development of the competences of media awareness, creative production and civic participation.

According to teachers, students rarely know what they are choosing to study when they select media literacy as an optional subject, since many think this is a journalism or an ICT course. In their opinion, students make the decision based on the positive impressions of older students, the good impression of the teacher and a fair probability to get a good grade-this last criteria was identified as relevant for students when selecting all optional subjects in a recent study assessing the education system reform (Bešić \& Reškovac, 2012).

\subsection{Curriculum}

All teachers interviewed differentiate media literacy from other types of literacy like the traditional language literacy or ICT literacy. 


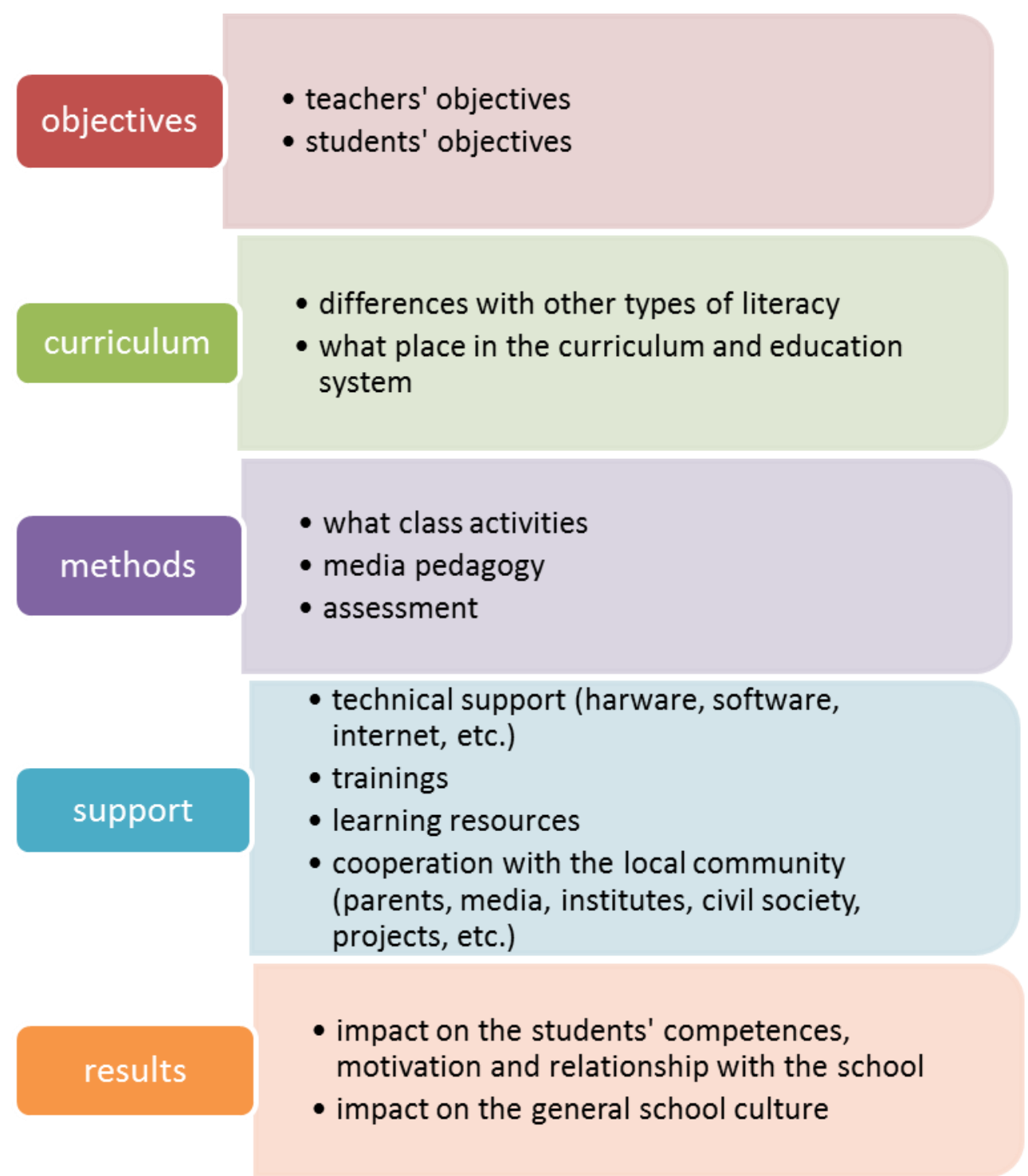

Figure 2. Research areas of the qualitative research on media literacy in Montenegro.

As pointed out by the interviewee $\mathrm{T} 2$, although critical analysis of media messages has points in common with the analysis of literary works:

"it is much more difficult to critically analyze a literary work than a media message....We often do this in parallel when we analyze together a movie made according to a book as a media message and the book as a literary work. I asked my students to pick a novel and to write an ad for it....To do this, they have to know what the novel is about and its characters and so, this also becomes a critical analysis and such activities can be done in parallel with the analysis of a literary work."

Teachers see media messages as more related to the present and everyday life, while literary works are less dynamic and more related to the past. "If the newspapers lose the moment and the information, there is no possibility of repetition and this makes media literacy alive and more related to the reality of everyday life", T3 explained.

Further, teachers point out to the need to teach students to read digital texts within the media literacy classes, since they present different characteristics compared to the traditional ones as pointed out by many scientists as well (Ferri, 2011; Perez Tornero \& Varis, 2010; Simone, 2012; etc.).

Key difference between the media and ICT literacy underlined by Montenegrin teachers is the absence of critical analysis in the ICT classes. One of them, T4, explains it in this way:

"While students learn things related to the computer, whether it is about hardware or software, they do not reflect on it critically....Therefore, there is a difference: in the first case, we have memorization of information, while media literacy asks for a different thing-it asks for a critical analysis of everything that the media transmit into the public sphere." 
Teachers rely on students' ICT literacy for media production and this is where they say that peer education is essential. Media literacy teachers do not have much cooperation with the ICT teachers though, apart from the use of the ICT labs.

According to the interviewed teachers, media literacy should be introduced into the curriculum of the entire education system starting from the preschool level. This would support the education of critical and active citizens in the digital age. However, they do not think it is realistic for media literacy to become a mandatory part of the already overcrowded curriculum of primary and high schools. They, rather, see it as an optional subject or an extracurricular activity. Some of them say that it is easier to teach media literacy to older students and are not sure if it can work with young children. Some teachers underline the need to introduce media literacy in professional high schools in particular, because they are generally attended by students with lower academic achievements and media literacy can motivate them and change positively their relationship with the school.

\subsection{Teaching Methodology}

Teachers describe critical analysis of media messages as the dominant in-class activity, while media production is done as homework, since there is not enough time for students to do it during 90 min of media literacy classes per week. They say that peer education is crucial for media production activities due to the intergenerational and digital divides. According to the teacher T1:

"It is clear that between them and me, as a teacher with 33 years of experience, there is a gap and that I am an immigrant compared to my students who possess more advanced technological knowledge than me.... The fact that they can teach these things means a lot to them, it makes them self-confident, it makes the classes interactive..."

Media messages made by students are regularly presented, discussed and assessed in class. They are often presented to the entire school during special events and celebrations. Teachers say that students find this practice quite motivating.

Teachers assess primarily students' participation during all classes, but they recognize the challenges of assessing individual contributions to the group work. They say to organize the class in a way to allow students' media messages to be regularly assessed by their peers in class. These messages are also evaluated by other people when presented at special events in school or uploaded online. The lack of uniform criteria or guidance for specific grades is perceived as a weakness by some teachers. Also, they recognize the chal- lenges of measuring different levels of competences achieved by students.

Finally, teachers see themselves as "cultural mediators" (Morcellini, 2007) and not as "traditional authorities" during the media literacy classes. "It is essential for the teacher to reject the position of the holder of absolute knowledge and to approach the student and treat him/her as a collaborator", teacher T1 points out.

Therefore, having in mind that the pedagogy described by Montenegrin teachers includes both critical analysis and media production, that the class is described as interactive and collaborative and that the assessment is said to be participatory as well, one can say that the teaching methodology is in line with the recommendations of many scientists (Gee, 2013; Hobbs, 2011; Hoechsmann \& Poyntz, 2012; Jenkins \& Kelley, 2013; Jones \& Hafner, 2012; Perez Tornero \& Varis, 2010; Veen \& Vrakking, 2006; etc.)

\subsection{Support Provided to Teachers}

The situation in relation to the technical support varies from one school to another. In general, teachers complain about the limited access to the computer lab and internet in school, the lack of cameras for making short movies with students and of a software for editing them. So, students make movies and photos on their cell phones and download a software for editing movies on their own as well.

The fact that some teachers complain about not easily accessing good quality equipment in school suggests that providing technology to schools is not enough, as the way that it is used defines its utility for the learning process. (Cortoni, 2009; Jenkins, 2010; Livingstone, 2009; Morcellini, 2007, etc.) Therefore, the school culture needs to change in order to ensure that the greatest number of students benefits from the available resources.

The issues described by Montenegrin teachers are similar to the ones faced by their colleagues in other European countries:

"although the situation varies greatly from country
to country, research asserts an insufficient access to
digital equipment in schools across Europe. While
the ultimate focus of ML is certainly not on tech-
nology, poor access to ICT equipment and to
broadband penalizes teachers and students' confi-
dent media use." (Celot, 2014, p. 9)

Further, some teachers point out that school libraries do not have newspapers or magazines that can be used in class. Teachers have to ask students to bring them or to buy them themselves in order to analyze more recent media messages.

As far as trainings are concerned, almost all teachers interviewed have finished one of the two media lit- 
eracy trainings organized in 2009, right before this optional subject was introduced. These trainings were about the programme and teaching resources and teachers say to have found them useful. However, they regret that no more trainings were organized afterwards and that there are no opportunities for teachers to share experiences. Some teachers underline the need for a specific training related to the film editing software, while others are more interested in learning more about effective media pedagogy.

New teachers who started teaching this optional subject after 2009 did so with no training and they say that this presented them with additional challenges.

The situation described by Montenegrin teachers is not much different from the general one in other European countries. In fact, the recent recommendation to the EU countries to organize media education training courses for primary and high school teachers and to offer them to all teachers is valid for Montenegro as well. Moreover, it is recommended that the professional teacher education includes acquiring all media literacy competences and that a media education curriculum is made for teachers' education. (Celot, 2014). Resources like the UNESCO Media and Information Literacy Curriculum for Teachers (Grizzle \& Wilson, 2011) can be useful, but they need to be adapted to the local context. Finally, more attention needs to be paid to the assessment of teacher trainings in order to ensure their effectiveness, as they often seem to be too focused on the theory. (Celot, 2014; Vos, Terryn et al., 2013)

As far as learning resources are concerned, all teachers have received the translation of the MediaLit Kit, which contains scenarios for in class activities, as well as two CDs with media messages to be used in class and a copy of articles and chapters written by different local and international authors on the sociology of media and culture, media theory, etc.

Most of the interviewed teachers say that a local media literacy textbook needs to be made, as no such thing is available at the moment. Some of them underline the need to have access to more creative learning resources. They also suggest changes the programme-it needs to focus more on media ethics and privacy. Some of them see as artificial the division of the programme in seven modules to be studied one after another. According to the teacher T5:

"A disadvantage of the programme is that the seventh module happens in May and so, only then we should start talking about the profit....You cannot share a media message and analyze it without coming to the conclusion that the aim is related to the profit or to the fact that someone wants to sell a certain product. You cannot start talking about such things only in May. Something needs to be changed in the programme."
Situation described by Montenegrin teachers on this point again is not much different from the one related to the EU countries. The need to develop innovative and efficient learning resources for media literacy courses in local languages is present in Europe too and it is recommended to achieve this in cooperation with the local teachers and media experts in order to better respond to the needs of the students of each country (Celot, 2014, p. 9). Also, these resources need to be evaluated and improved continuously through research on how media literacy is taught in class and its impact. (Celot, 2014, p. 13)

As far as cooperation is concerned, teachers point out that there is no effective network of all schools in the country and so, opportunities for them to exchange experiences and collaborate are scarce. Regarding this aspect, Montenegro is behind some European countries which have institutes in charge of developing, researching and organizing collaboration and networking in relation to media literacy such as the Finnish Centre for Media Education. However, not all EU countries have achieved this level and so, the general recommendation to them to establish networks, media education online platforms and observatories is also valid for Montenegro. (Celot, 2014, p. 15)

Teachers say that there is little cooperation with parents outside the issues related to the academic achievement of students. Moreover, the level of parents' awareness of media literacy is generally low and so, there is not much interest for collaboration on this particular issue. Teachers describe sporadic episodes when some parents came to the presentations of students' media products. Teachers say that parents often share what the children say at home about media literacy classes, as these are highly positive impressions.

Teachers describe many challenges related to the cooperation with the local media. In some municipalities, they do not exist, while, in others, local media are experiencing significant economic difficulties. Teachers identify the lack of funds for covering the transport costs for students to visit the national media in the capital as a significant challenge too.

However, there are positive experiences, such as the ten year cooperation between the Gymnasium in Tivat and local Radio Tivat. The media literacy teacher in this school involves media literacy and other students in making a radio show for their peers within the journalism section that started before media literacy was introduced as an optional subject. Also, they make a school magazine and they visit two national TV stations in the capital every year. Further, they get free tickets for students to attend the performances in the local Cultural Centre and they discuss these experiences during media literacy classes. The teacher emphasizes that media literacy students find these activities quite useful.

Having in mind the situation described, a recent 
recommendation to the EU countries to involve media professionals in media literacy trainings and to promote more active engagement of local media in media literacy, within their corporate social responsibility activities, is relevant for Montenegro as well. (Celot, 2014, p. 11)

Few teachers say to have taken part in media literacy projects. Those who have describe them as related to international seminars on media literacy for Eastern European students, who, during this time, work together on producing different media messages. They say that such experiences are quite motivating, but are sporadic, as teachers lack information about opportunities to apply for funding.

Therefore, on this point as well, the recommendation made to the EU countries to incorporate media literacy in lifelong learning and to stimulate projects of cooperation with the civil society in local communities in order to support citizens with diverse backgrounds to acquire media literacy competences is relevant for Montenegro as well. (Celot, 2014, p. 12)

\subsection{Impact}

Interviewed teachers see in media literacy a subject that can help students to learn how to learn and to improve their academic achievement, since in these classes they learn to quickly identify key information from the less important ones. They also agree that competences developed through the media literacy course support students to achieve better results at tests like the PISA, which is often discussed in public debates and used as an indicator of the quality of the education system.

They underline that media literacy increases students' motivation and often changes positively their relationship with the school. According to the teacher T6:

"The ones who are doing well, become even better students as they gain access to new ways to conceptualize their knowledge and see that there are different models for applying this knowledge. The ones who are not doing great in school become more self-confident and relaxed in school, because they feel more welcome."

Teachers recognize the potential of media literacy to change the school culture positively. "There is no subject with which it is not correlated and to which it cannot be applied", teacher T7 explains. However, for this potential to be realized, its pedagogy needs to be applied systematically to the subjects, as pointed out by the teacher T8: "group work, collaborative learningthese things are mentioned in trainings for other subjects as well, but here they must be practiced, as there is no other way to teach media literacy". Hence, both peer education and "participatory assessment" (Jenkins \& Kelley, 2013) are identified in interviews as in- novative and useful practices of media literacy pedagogy that should be used when teaching other subjects as well.

It is significant that teachers say that they spontaneously started applying the pedagogy they use in media literacy classes when teaching other subjects as well. "Yes, I changed the way of teaching the language and literature after my experience with teaching media literacy.... applied some group work, learning through research done by students...", teacher T9 explains.

Moreover, teachers say that their relationship with the students changed as they changed their role from being an authority in the classroom to being a coordinator or a "cultural mediator" (Morcellini, 2007). Teacher T1 explains:

"the relationship between the teacher and the student is not authoritative in the sense that my students are afraid of me and listen to me as if I were a saint. No, we work in cooperation.....And so, even my literature classes improved...as simply different teaching methods were combined..... believe that media literacy offers a good balance and that it shifts the school towards a new methodology."

In order for the school culture to change, all teachers need to adopt effective practices of media literacy pedagogy in their classes every day. However, at the moment, interviewed teachers underline that there is little interest for media literacy among their colleagues and that this is due to the low motivation of teachers in general. "Teachers are underestimated, have low salaries and are placed at the margins of the society", teacher T10 explains.

Montenegro's situation on this point is similar to the one described for many EU countries (Vos et al., 2013). Therefore, in order to change positively the school culture, media literacy teachers need to become the change-agents of the education system. For this to happen, they need to have more and better quality trainings. In other words, they need to become a critical mass leading the improvement of the education system, while now, as they describe in the interviews, they are often isolated and left on their own to challenge the dominant culture and "the way of doing things" in order to put their ideas into practice.

\section{Conclusions}

Interviews with Montenegrin media literacy teachers indicate that they have improved their pedagogy as a result of teaching this course and that through the study of this optional subject students have increased motivation, changed positively their relationship with the school and strengthened critical thinking. Therefore, if spread through the entire education system from preschool level on, media education can help its 
reform and serve as a precursor to the new digital education paradigm.

The possibility of applying media education pedagogy to social sciences is already recognized in the programme of this optional subject, but it has still not become a reality, as indicated by the recent assessment of the education reform outcomes (Bešić \& Reškovac, 2012). Hence, this research recommends adopting media education as a new paradigm for Montenegrin education and to center the reform on spreading the media education pedagogy to the entire curriculum.

The research has also identified the key challenges that media education is facing in Montenegro, some of which are common to the entire education system (Bešić \& Reškovac, 2012). In summary, the challenges are related to the lack of pre-service and in-service teacher trainings, technical support, good quality learning resources, efficient indicators for students' assessment, research on the impact of the curriculum, teacher trainings and learning resources, and the lack of opportunities for collaboration with the local community.

Hence, according to Montenegrin teachers, to develop media education in Montenegro, the following steps need to be undertaken in future:

1. improve its status;

2. improve cooperation with media and local communities;

3. provide teacher trainings regularly and establish a network of media literacy teachers;

4. improve technical support and learning resources;

5. spread media education to all levels starting from the preschools.

If the information collected through this qualitative research is compared with the criteria for media literacy assessment in European countries (Perez Tornero \& Celot, 2009), which include indicators related to four areas-media education, media literacy policy, media industry and civil society, Montenegro would be assessed as a country with a "basic" level of media literacy. (There is no policy on media literacy; participation of the media industry and civil society is sporadic; only two teacher trainings were organized; learning resources are scarce; the programme was never assessed and it is limited to a one year optional course for 16-17 year old students.)

The lack of a media literacy strategy distinguishes countries with a low media literacy level from the ones with a medium or high level (Frau-Meigs \& Torrent, 2009; Perez Tornero \& Celot, 2009). Therefore, the recommendation to EU countries to improve the media literacy level of the society by producing a media literacy strategy would be valid for Montenegro (Perez Tornero \& Celot, 2009, p. 78).

Also, recent policy recommendations from the $\mathrm{EU}$
Kids Online (Livingstone, Mascheroni, Olafsson, \& Haddon, 2014) are relevant to Montenegro and are in line with the recommendations from this qualitative research. In particular, a national strategy with an action plan should target children, parents, educators, government, media and ICT industry. It needs to include voices of youth and to raise awareness of media education. A good example in regard is the Finnish Media Literacy Policy Guidelines 2013-2016, which includes cooperation of all sectors of the society-national and local authorities, civil society, private sector, media, teachers, parents and children.

To conclude, Montenegro should embrace a strategic approach towards media education in future and this will benefit its entire education system. By spreading the media education pedagogy to the entire curriculum and embracing the digital education paradigm, Montenegrin schools will teach more effectively the competences that students need in the $21^{\text {st }}$ century, as well as improve the quality of education.

\section{Conflict of Interests}

The author declares no conflict of interests.

\section{References}

Aufderheide, P. (1993). Media Literacy. A report of the national leadership conference on media literacy. Aspen: Aspen Institute.

Bešić, M., \& Reškovac, T. (2012). Evaluacija reforme obrazovanja u Crnoj Gori (2010-2012). Podgorica: Mreža fondacija za otvoreno drustvo. Retrieved from http://www.zzs.gov.me/ResourceManager/FileDown load.aspx?rld=119598\&rType $=2$

Carrington, V., \& Robinson, M. (Ed.) (2009). Digital Literacies: Social Learning and Classroom Practices. London, UK: Sage Publications.

Celot, P. (2014). Media literacy European policy recommendations. Brussels: EAVI. Retrieved from http://www.eavi.eu/joomla/images/stories/About_E AVI/eavi\%202014\%20media\%20literacy\%20eu\%20p olicy\%20recommendations.pdf

Chaka, C. (2009). The changing faces of literacies: Information and media literacy in the context of higher education. In M. Leaning (Ed.), Issues in information and media literacy: Education, practice and pedagogy. Santa Rosa, CA: Informing Science Press.

Christ, W. G., \& Potter, W. J. (1998). Media literacy, media education and the academy. Journal of Communication, 48(1), 5-15.

Cortoni, I. (Ed.) (2009) Una scuola che comunica. Volume 1. Trento: Erickson.

Cortoni, I., \& Lo Presti V. (2014) Digital capabilities. In S. Kotilainen \& R. Kupiainen (Eds.), Reflections on media education futures. Contributions to the conference media education futures in Tampere, Finland 
2014. Göteborg, Sweden: Nordicom.

Crystal, D. (2001). The language of the Internet. Oxford: Oxford University Press.

Davies, J. (2009). A space for play: Crossing boundaries and learning online. In V. Currington \& M. Robinson (Eds.), Digital literacies: Social learning and classroom practices. London, UK: Sage Publications.

Dowdall, C. (2009). Masters and critics: Children as producers of online digital texts. In V. Carrington \& Robinson M. (Eds.), Digital literacies: Social learning and classroom practices. London, UK: Sage Publications.

Ferri, P. (2011) Nativi digitali. Milano: Pearson Italia.

Frau-Meigs, D., \& Torrent, J. (Eds.) (2009). Mapping media education policies in the world: Visions, programmes and challenges. New York: UN-Alliance of Civilizations and GrupoComunicar.

Gee, J. P. (2008). Social linguistic and literacies: Ideology in discourse. London, UK: Routledge.

Gee, J. P. (2013). The anti-education era: Creating smarter students through digital learning. New York, USA: Palgrave Macmillian.

Goldhaber, M. H. (1997). The attention economy and the net. First Monday, 2 (4-7). Retrieved from http://firstmonday.org/article/view/519/440

Grizzle, A., \& Wilson, C. (Ed.) (2011) Media and information literacy curriculum for teachers. Paris: UNESCO. Retrieved from http://unesdoc.unesco.org/images/ 0019/001929/192971e.pdf

Hobbs, R. (2010). Copyright clarity: How fair use supports digital learning. Thousand Oaks, CA: Corwin.

Hobbs, R. (2011). Digital and media literacy: connecting culture and classroom. London: Sage.

Hoechsmann, M., \& Poyntz, S. R. (2012). Media literacies: A critical introduction. West Sussex: WileyBlackwell.

Ito, M., Horst, H., Bittanti, M., Boyd, D., HerrStephenson, B., Lange, P. G., Pascoe, C. J., \& Robinson L. (2009). Living and learning with new media. Summary of Findings from the Digital Youth Project. London, England: The MIT Press.

Jenkins, H. (2010). Culture partecipative e competenze digitali. Media Education per il XXI secolo. Milano: Angelo Guerini e Associati SpA.

Jenkins, H., \& Kelley, W. (2013). Reading in a participatory culture: Remixing Moby-Dick in the English classroom. New York, USA: Teachers College, Columbia University.

Jones, R. H., \& Hafner, C. A. (2012). Understanding digital literacies: A practical introduction. New York, USA: Routledge.

Kerin, R. (2009). Digital portraits: Teacher education and multiliteracies pedagogy. In V. Carrington \& M. Robinson (Eds.), Digital literacies: Social learning and classroom practices. London: Sage Publications.

Lankshear, C., \& Knobel, M. (Eds.) (2007). Digital literacies: Concepts, policies and practices. New York: Pe- ter Lang.

Leander, K. (2009). Composing with old and new media: Toward a parallel pedagogy. In V. Carrington \& $\mathrm{M}$. Robinson (Eds.), Digital literacies: Social learning and classroom practices. London: Sage Publications.

Lessig, L. (2004). Free culture: How big media uses technology and the law to lock down culture and control creativity. New York: Penguin Press.

Livingstone, S. (2009) Children and the Internet: Great expectations, challenging realities. Cambridge, UK: Polity Press.

Livingstone, S., Mascheroni, G., Olafsson, K., \& Haddon, L. (2014). Children's online risks and opportunities: comparative findings of EU Kids Online and Net Children Go mobile. Retrieved from http://www. netchildrengomobile.eu/reports

Manovich, L. (2007). What comes after remix? Retrieved from http://manovich.net/DOC-S/remix_2007_2.doc

Mazzarella, S. R. (Ed.) (2007). 20 questions about youth \& the media. New York: Peter Lang.

McWilliams, J. E., \& Clinton, K. (2013). Reimagining and reinventing the English classroom for the digital age. In H. Jenkins \& W. Kelley (2013), Reading in a participatory culture: Remixing Moby-Dick in the English Classroom. New York, USA: Teachers College, Columbia University.

Montgomery, K. C., Grier, S., Chester, J., \& Dorfman, L. (2011). Digital marketing e children's health. A framework for research. In C. VonFeilitzen, U. Carlsson, \& C. Bucht (Eds.), New questions, new insights, new approaches. Contributions to the research forum at the world summit on media for children and youth 2010. Göteborg, Sweden: International Clearinghouse on Children, Youth and Media, Nordicom, Göteborg University.

Morcellini, M. (2007). Conclusione. In M. Morcellini \& P. C. Rivoltella (Eds.), La sapienza di comunicare. Dieci anni di media education in Italia ed Europa. Gardolo: Erickson.

Morcellini, M., \& Cortoni, I. (2007). Provaci ancora, scuola. Idee e proposte contro la svalutazione della scuola nel Tecnoevo. Trento: Erickson.

Morrel, E., Duenas, R., Garcia, V., \& Lopez, J. (2013). Critical media pedagogy. Teaching for achievement in city schools. New York, USA: Teachers College, Columbia University.

Perez Tornero, J. M., \& Celot, P. (2009). Study on assessment criteria for media literacy levels. Brussels: EAVI, CLEMI, UAB, UCL, UTA, European Commission. Retrieved from http://ec.europa.eu/culture/library/ studies/literacy-criteria-report_en.pdf

Perez Tornero, J. M., \& Varis, T. (Eds.) (2010). Media literacy and new humanism. Moscow, Russia: UNESCO.

Potter, J. (2013). Media literacy. London, UK: Sage Publications.

Simone, R. (2012). Presi nella rete. Milano: Garzanti.

Veen W., \& Vrakking B. (2006) Homo Zappiens. Crescere 
nell'era digitale. Roma: Edizioni Idea.

Vos, I., Terryn, D., Boshkov, A., Fotiade, N., Grousouzakou, E., Kovachev, L., Kamburova, N., Lõssenko, J., Newrly, P., Papadimitriou, S., Reynolds, S., Sedlbauer, G., Simmetsberger, U., Tokmakidou, X.,
\& Tsakarestou, B. (2013) Charting media and learning in Europe 2013. Retrieved from http://www.medeanet.eu/sites/default/files/MEDEA net_Deliverable_4.3_Annual_Report_2013/index.pdf

\section{About the Author}

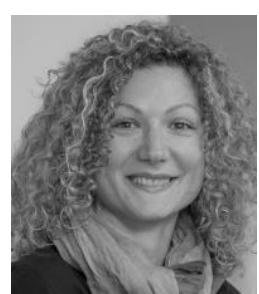

\section{Dr. Jelena Perović}

Jelena Perović has a PhD in Communications Science from the Sapienza University of Rome, Italy. The PhD thesis is entitled "Media Literacy in Montenegro". She has been working for UNICEF Montenegro as the Communication Officer since 2007. Previously, she worked for Save the Children. 